\title{
A screening method for the detection of Brucella antibodies in human serum
}

\author{
P. M. HINCHLIFFE, L. ROBERTSON, AND I. D. FARRELL \\ From the Public Health Laboratory, Royal Infirmary, Preston
}

SYNOPSIS The antiglobulin consumption test of Steffen (1954) has been adapted for the detection oif Brucella antibodies in human serum.

This screening method takes approximately two hours to complete and sera which give a negative्ठ result need no further investigations, whilst positive sera should be fully tested by the conventiona $\$$ Brucella serology technique.

Steffen (1954) devised the antiglobulin consumption test for the detection of autoantibodies on tissue cells. He demonstrated a reduction in the titre of antihuman globulin when it had been exposed to tissue cells onto which autoantibodies had been adsorbed.

This paper describes an adaptation of this technique as a screening test for detecting brucella antibodies in human serum and compares its efficacy with conventional serological tests.

\section{Materials and Methods}

HUMAN SERA

Specimens of human serum were used without heat inactivation.

\section{BR UCELLA ANTIGEN}

A concentrated suspension of killed $B$. abortus was supplied by Veterinary Laboratories of the Ministry of Agriculture, Fisheries and Food, Weybridge, England (Weybridge standardized $B$. abortus 'agglutination concentrate').

ANTIHUMAN GLOBULIN

Wellcome Coombs reagent.

ERYTHROCYTE INDICATOR SYSTEM

Ortho Coombs control (Ortho Diagnostics), diluted 1 in 2.

DILUENT

Oxoid complement fixation-test diluent tablets.

\section{Antihuman Globulin Titration}

The Coombs reagent is titrated in $0.2 \mathrm{ml}$ amounts iमै WHO trays using doubling dilutions. To eacti dilution is added $0.02 \mathrm{ml}$ of the suspension of sensitized erythrocytes, and the tray is shaken te suspend the red cells evenly, then left for 30 minutes at room temperature. The cells are then resuspende and allowed to settle for a further 15 minutes an examined for agglutination.

The titre of the AHG is the highest dilution showing partial agglutination of the sensitized red cells.

Preliminary experiments have indicated that the optimal working strength of the AHG is 16 times stronger than the agglutinating titre (see Appendix

\section{TEST}

In the first series of antihuman globulin consump을 tion (AHGC) tests the patient's serum and the antigen suspension were diluted 1 in 5 , and in the secons. series they were diluted 1 in 10 .

To $0.5 \mathrm{ml}$ of the serum dilution in a $50 \mathrm{~mm} x^{N}$ $9 \mathrm{~mm}$ round bottom tube is added $0.5 \mathrm{ml}$ of the appropriate dilution of $B$. abortus antigen.

The tube is incubated for 15 minutes in a wateo bath at $37^{\circ}$ and then centrifuged at $1400 \mathrm{~g}$ fob 15 minutes. The supernatant is poured off ans drained by inverting the tube against filter paperis The deposit is resuspended in $1 \mathrm{ml}$ of diluent usingo a Vortex mixer. At this stage the antigen ma@ agglutinate especially in serum subsequently shown to have an SA titre $>1: 160$. A further $1 \mathrm{ml}$ of diluen $\vec{D}$ is added before centrifuging at $1400 \mathrm{~g}$ for 15 minute and the supernatant then removed as before. This procedure is repeated twice more. To reduce the 


\begin{tabular}{|c|c|c|c|c|c|c|c|c|c|c|}
\hline \multirow{3}{*}{$\begin{array}{l}\text { AHGC } \\
\text { Result }\end{array}$} & \multicolumn{10}{|c|}{ Reciprocal of Titre } \\
\hline & \multicolumn{4}{|c|}{ SA Test } & \multicolumn{3}{|c|}{ ME Test } & \multicolumn{3}{|c|}{ CF Test } \\
\hline & $<20$ & 20 & $40-160$ & $>160$ & $<20$ & 20 & $\geqslant 40$ & $<20$ & 20 & $\geqslant 40$ \\
\hline \multicolumn{11}{|c|}{ First Series } \\
\hline+ & 46 & 13 & 30 & 14 & 72 & 4 & 27 & 57 & 7 & 39 \\
\hline - & 133 & 8 & 2 & 0 & 143 & 0 & $\mathbf{0}$ & 143 & 0 & 0 \\
\hline \multicolumn{11}{|c|}{ Second Series } \\
\hline+ & 9 & 5 & 17 & 12 & 19 & 2 & 22 & 14 & 8 & 21 \\
\hline- & 170 & 21 & 9 & 0 & 199 & 1 & 0 & 199 & 1 & 0 \\
\hline
\end{tabular}

Table I Comparison between the AHGC test and three conventional serology tests in the examination of human sera for the presence of Brucella antibodies

possibility of false positives this antigen-washing procedure should be strictly observed.

After the supernatant from the third washing has been removed, $0.2 \mathrm{ml}$ of the optimal working dilution of the AHG is added to the deposit and the antigen resuspended. A minimum contact time of five minutes should be allowed before centrifuging at $1400 \mathrm{~g}$ for 15 minutes.

The supernatant is carefully removed and transferred to a well in a WHO plate. To this is added $0.02 \mathrm{ml}$ (1 drop from a 50 dropper) of sensitized RBCs, the plate is shaken, and then left at room temperature for 15 minutes. The plate is again gently shaken, and examined for agglutination after a further 15 minutes at room temperature. The absence of agglutination of the sensitized RBCs indicates consumption of the AHG due to the presence of brucella antibodies in the patient's serum.

The degree of agglutination can be graded from 0 to $4+$ (the latter signifying no AHG consumption, resulting in complete agglutination with a clear supernatant) and any result other than $4+$ indicates some consumption of antihuman globulin.

The methods for the standard agglutination (SA), mercaptoethanol agglutination (ME), complementfixation (CF), and antihuman globulin (Coombs) tests have been described elsewhere (Farrell,
Hinchliffe, and Robertson, 1974). A positive Coombs test is defined as having a four-fold increase in titre compared with the SA test.

\section{Results}

In the first series of 246 sera, 166 were serologically negative, and of these $34(21 \%)$ were AHGCpositive. The 80 sera which were positive with one or more of the conventional serological tests included $11(14 \%)$ sera which were AHGC-negative (table II). It is evident from table II that the majority of these 11 sera had a low SA titre only. All sera containing either ME-resistant agglutinins or CF antibodies were AHGC-positive.

In the second series of 243 specimens only four $(2 \%)$ of the 170 serologically negative sera were AHGC-positive. Of the 73 sera which were positive by at least one of the conventional tests, $31(42 \%)$ were AHGC-negative, and the breakdown of these results (table II) shows that only one of these specimens was positive by more than one conventional test, the majority having an SA titre of 1 in 20 only. Although the sensitivity of the AHGC test had been reduced in this second series, 24/25 $(96 \%)$ sera with ME-resistant agglutinins and 29/30 (97\%) sera with CF antibodies were AHGCpositive (table I).

\begin{tabular}{|c|c|c|c|c|c|}
\hline & & \multicolumn{4}{|c|}{ Routine Serology Tests (SA, ME, CF, and Coombs) } \\
\hline & & \multicolumn{2}{|l|}{ All Negative } & \multicolumn{2}{|c|}{ At Least One Positive } \\
\hline & & First Series & Second Series & First Series & Second Series \\
\hline $\begin{array}{l}\text { AHGC } \\
\text { Total }\end{array}$ & + & $\begin{array}{r}34 \\
132 \\
166\end{array}$ & $\begin{array}{r}4 \\
166 \\
170\end{array}$ & $\begin{array}{l}69 \\
11^{1} \\
80\end{array}$ & $\begin{array}{l}42 \\
31^{2} \\
73\end{array}$ \\
\hline
\end{tabular}

Table II Results of testing Brucella antibody-positive and antibody-negative human sera with the AHGC test

$\begin{array}{lc}18 \text { specimens SA } 1: 20 \text { only } & 220 \text { specimens SA } 1: 20 \text { only } \\ 1 \text { specimen SA } 1: 40 \text { only } & 6 \text { specimens SA 1:40 only } \\ 1 \text { specimen SA } 1: 80 \text { only } & 1 \text { specimen SA } 1: 80 \text { only } \\ 1 \text { specimen Coombs } 1: 40 \text { only } & 1 \text { specimen SA } 1: 160 \text { only } \\ & 1 \text { specimen SA } 1: 80, \text { ME } 1: 20, \text { CF }<20 \\ & 1 \text { specimen CF } 1: 20 \text { only } \\ & 1 \text { specimen Coombs } 1: 40 \text { only }\end{array}$


In the first series 27 sera were Coombs testpositive of which $26(96 \%)$ were AHGC-positive; the AHGC-negative serum contained neither agglutinins nor $\mathrm{CF}$ antibodies. Two sera were Coombstest positive in the second series both of which were AHGC-positive.

\section{Discussion}

The method described is intended as a screening procedure in the examination of human sera for brucella antibodies. The sensitivity of the test can be adjusted by varying the concentration of antihuman globulin, patient's serum, or antigen. Table I shows that the number of AHGC-positive results in each of the three serological negative $(<1: 20)$ groups was four to five times greater in the first series than in the second series. Furthermore, of the specimens which were negative by all four conventional tests, $34(20 \%)$ were AHGC-positive in the first series and only four $(2 \%)$ in the second series. These results indicate that an antigen dilution of $1: 10$ is suitable for routine use.

There is evidence that patients who do have CFor ME-resistant antibodies in their serum are more likely to have an active Brucella infection than those who do not (Farrell et al, 1974). In the first series of tests the AHGC was positive with all sera, containing either ME-resistant agglutinins or $\mathrm{CF}$ antibodies. In the second series although the sensitivity of the test was reduced only one serum containing ME-resistant agglutinins $(1: 20)$ and one serum containing $C F$ antibodies $(1: 20)$ were AHGC-negative.

Antihuman globulin is very sensitive to traces of human serum and should the Coombs reagent be neutralized by contamination with human serum the AHGC would be positive and the specimen further investigated. In contrast, should a similar circumstance affect the conventional Coombs test the result would be a negative reading. To reduce the probability of false positives the antigen washing routine should be strictly observed

With regard to false-negative results, table I shows that nine of the 26 sera in the second series which had a SA titre of 1:40-1:160 gave negative AHGC results; all were CF $<1: 20$, AHG test negative, and, with one exception, $\mathrm{ME}<1: 20$.
Of the 26 sera which had a SA titre of $1: 20,2$ were AHGC-negative; all other serological test. were negative, except in one case where the $\mathrm{C}$ EO test had a titre of $1: 20$.

It was found that most sera which had a $S$ titre $\geq 1: 160$ showed obvious agglutination o being resuspended after the first centrifugation Hall and Manion (1953) have shown that a propor:tion of sera with incomplete agglutinins detectable by the Coombs test will also agglutinate on centri $\vec{\omega}$ fugation. One of the specimens in the second serieg had the following titres: Coombs $1: 160, \mathrm{SA}<1: 20 \%$ $\mathrm{ME}<1: 20$, CF $1: 20$. This specimen did not aggluro tinate when centrifuged, but the AHGC test was. positive.

Many of the specimens used in the present invest gations showed a prozone in the SA test, one of then having a marked prozone to a dilution of 1 in 80. The AHGC was positive and appears to be a reliable test for the screening of such specimens.

\section{Appendix}

The following procedures were designed to determine the optimum concentration of reagents and cong ditions of reaction.

\section{INDICATOR SYSTEM}

Doubling dilutions of AHG were allowed to reasis with various concentrations of sensitized cells ait room temperature (Table III).

One drop from a 50 dropper of sensitized cel 8 diluted $1: 2$ gave the clearest haemagglutination pattern.

The test was also carried out at $37^{\circ}$ with $n$ difference in results.

The titre was taken as $1: 2400$. The optimumb working dilution would be 16 times greater, or $1: 15$ ?

ANTIGEN CONCENTRATION

A chessboard titration was carried out using a serurg of low Brucella antibody titre by conventiona serology.

\begin{tabular}{|c|c|c|c|c|c|c|c|}
\hline \multirow[t]{2}{*}{ Sensitized Cells } & \multicolumn{6}{|c|}{ AHG Concentrut ons } & \multirow[b]{2}{*}{ Diluent $C$} \\
\hline & $1: 150$ & $1: 300$ & $1: 600$ & $1: 1200$ & $1: 2400$ & $1: 4800$ & \\
\hline 2 drops & 4 & 4 & 4 & 4 & 1 & 0 & 0 \\
\hline 1 drop & 4 & 4 & 4 & 4 & 2 & 1 & 0 \\
\hline 1 drop of $1: 2$ cells & $\operatorname{ls} 4$ & 4 & 4 & 4 & 2 & 1 & 0 \\
\hline
\end{tabular}




\begin{tabular}{|c|c|c|c|c|c|c|}
\hline \multirow[t]{2}{*}{ Serum } & \multicolumn{6}{|c|}{ Antigen Dilutions } \\
\hline & $1: 5$ & 10 & 20 & 40 & 80 & 160 \\
\hline $1: 10$ & 0 & 0 & 0 & 1 & 4 & 4 \\
\hline 20 & 0 & 0 & 0 & 1 & 4 & 4 \\
\hline 40 & 1 & 2 & 3 & 4 & 4 & 4 \\
\hline 80 & 3 & 3 & 3 & 4 & 4 & 4 \\
\hline 160 & 4 & 4 & 4 & 4 & 4 & 4 \\
\hline 320 & 4 & 4 & 4 & 4 & 4 & 4 \\
\hline Diluent & 4 & 4 & 4 & 4 & 4 & 4 \\
\hline
\end{tabular}

Using a 1:10 antigen dilution, the titre of the serum would be taken as $1: 40$, the same result as that of the SA titre.

\section{ANTIGEN SERUM REACTION TIME}

The test was carried out using both 15 minutes and 60 minutes reaction time at $37^{\circ}$. The two results did not differ, and therefore the shorter time was chosen.

\section{ANTIGEN WASHING PROCEDURE}

In order to determine the minimum number of washings necessary to free the antigen from serum, the supernatant from each of the three washings was used as a diluent in titrating the Coombs reagent (as described in the methods section). Antigen in diluent alone served as a negative control. The results showed that the supernatant from the first washing substantially reduced the AHG titre; the supernatant from the second washing reduced the AHG titre by one dilution; but that of the third and subsequent washings caused no reduction in titre.

\section{References}

Farrell, I. D., Hinchliffe, P. M., and Robertson, L (1974). Serum antibody response in acute brucellosis. (In preparation).

Hall, W. H., and Manion, R. E. (1953). Comparison of the Coombs test with other methods for Brucella agglutinins in human serum J. clin. Invest., 32, 96-106.

Steffen, C. (1960). Les applications de la réaction de consommation de L'antiglobuline aux études cliniques et expérimentales. Rev. franç. Étud. clin. biol., 5, 831-835. 